\title{
Identifying the Defendant in Products Liability Litigation: Alternate Theories for Compensating Injured Plaintiffs
}

\author{
Richard J. Hunter, Jr. \\ Professor of Legal Studies \\ Seton Hall University \\ United States
}

John H. Shannon

Professor of Legal Studies

Seton Hall University

United States

Henry J. Amoroso

Associate Professor of Legal Studies

Seton Hall University

United States

\begin{abstract}
A spirited public policy debate has raged in the United States for more than four decades revolving around the responsibility of drug manufacturers for their products that cause injury to unsuspecting plaintiffs. An important part of the debate centers around a drug-DES-that was marketed as a benefit to women in preventing miscarriages. Some interesting or "alternate" theories for assessing liability have received attention in the generic area of products liability. This article will discuss three of the most prominent and still controversial theories-alternative liability, enterprise liability, and market share liability. In addition, the article will include several case studies exemplifying the legal principles discussed - some coming to very difficult conclusions regarding the efficacy and application of these theories to particular facts developed during litigation.
\end{abstract}

Keywords: Alternative Liability; Enterprise Liability; Market Share Liability

\section{Introduction}

DES (Diethylstilbestrol, a synthetic form of the female hormone estrogen) litigation in the United States has been both extensive and controversial. Forty years ago, at the height of the DES crisis, in a seminal law review article in the Fordham Law Review, Sheiner (1978) estimated that the number of women who took DES during pregnancy ranged from 1 1/2 million to 3 million. Later estimates (Wajert, 2013; LawyersandSettlements.com, 2018) indicated that as many as 6 million women were given the drug between 1941 and the early 1970s. Sheiner (1978) also maintained that "hundreds, perhaps thousands, of the daughters of these women suffer from adenocarcinoma, and the incidence of vaginal adenosis among them is 30 to 90 percent" (p. 964).

With a very few exceptions, cases that have been decided in the courts have resulted in judgments in favor of drug company defendants because of the failure of the plaintiffs to identify with specificity the manufacturer of the DES which allegedly caused their injury. This is often referred to as the failure of the plaintiff to provide "proper identification." [Table 1 contains a list of the drug manufacturers that have been defendants in the various case studies found below.] Attempts to remedy what some believe are unjust or unethical results (Schoen, Hogan, and Falchek, 2000) have continued to vex courts, legislatures, and policy makers (Pham, 2014).

Hunter, Shannon, and Amoroso (2012) note that as a general proposition, the imposition of liability in products liability litigation depends upon a showing by the plaintiff that his or her injuries were caused by the act or omission of the defendant which rendered a product defective. A defect may be found in manufacturing (generally, Geistfeld, 2006a, pp. 71-133), design (Twerski and Henderson, 2009), or marketing (relating to proper warnings and labels) (Boeschen, 2018; see also Spruill v. Boyle-Midway Corporation, 1962). 
This general rule applies whether the injury resulted from negligence (e.g., Shunk v. Bosworth, 1964; Larson, 2018), from the creation of a defective product (e.g., Wetzel v. Eaton Corporation, 1973) based on a theory of strict liability in tort (e.g., Ray v. Alad Corp., 1977) found in the Restatement (2d) of Torts Section 403B, or under some other theory of recovery.

In attempting to define and broaden the scope of liability for certain manufacturers - most especially in the pharmaceuticals industry (Hunter and Dooney, 2014) - various plaintiffs have advanced theories of recovery stating that if a party cannot identify which of two or more defendants caused an injury, the burden of proof should be shifted to each of the defendants to show that they were not responsible for the harm. One of these theories is referred to as the "alternative liability" theory. It is now a settled basis of liability where more than one party has been identified as being negligent toward the plaintiff.

\section{Alternative Liability}

As Professor Geistfeld (2006b, p. 1) has noted, in its simplest form, "alternative liability permits the plaintiff to prove causation against a group of defendants" (p. 447). The case of Summers v. Tice (1948), exemplifies the principle - but in a different context. In Summers, the plaintiff was injured when two hunters negligently shot in his direction. It could not be determined which of them had fired the shot that had actually caused the injury to the plaintiff's eye, but both defendants were nevertheless held jointly and severally liable for the entire amount of the damages. The court found that both defendants were wrongdoers (tortfeasors), and that both defendants were negligent in their actions toward the plaintiff. Under these circumstances, it would be unfair to require the plaintiff to isolate and identify the particular defendant responsible for his injuries. The Summers court held that under these circumstances, the burden of proof would be shifted to each of the defendants, "each to absolve himself if he can," because under these or similar circumstances a defendant is ordinarily in a "far better position" to provide evidence to determine whether he or another defendant caused the injury.

The decision in Summers has closely tracked Section 433B, subdivision (3) of the Restatement $\left(2^{\text {nd }}\right)$ of Torts, which provides:

"Where the conduct of two or more actors is tortious, and it is proved that harm has been caused to the plaintiff by only one of them, but there is uncertainty as to which one has caused it, the burden is upon each such actor to prove that he has not caused the harm."

The reason underlying the rule, found in Restatement $\left(2^{\text {nd }}\right)$ of Torts, Section 433B, comment $\mathrm{f}$, is: "the injustice of permitting proved wrongdoers, who among them have inflicted an injury upon the entirely innocent plaintiff, to escape liability merely because the nature of their conduct and the resulting harm has made it difficult or impossible to prove which of them has caused the harm."

The Summers court relied upon the precedent of Ybarra v. Spangard (1944) in its decision. There, the plaintiff was injured during the course of surgery. He sought damages against several doctors and a nurse who had attended him while he was in fact unconscious. The court held that it would be unreasonable to require the plaintiff to identify the particular defendant who had performed the alleged negligent act because he was unconscious at the time of the injury and the defendants had exercised control over the instrumentalities which caused the harm. Therefore, under the doctrine of res ipsa loquitur ("the thing speaks for itself"), an inference of negligence arose under which the defendants were required to overcome by explaining their conduct or face the imposition of liability (see also Escola v. Coca-Cola Bottling Co. of Fresno, 1944).

The "alternative liability" theory is recognized as an appropriate method for assessing liability - but only if each of the parties can be shown to be negligent towards the plaintiff in the first place.

\section{Enterprise or Industry-Wide Liability}

The theory of "enterprise liability" has been suggested as a basis of assessing the potential liability of a defendant in a products liability suit where no specific evidence of fault exists against that particular defendant, but where the defendant is a part of an industry (termed the enterprise) that produced a product (e.g., Klemme, 1976). The theory of enterprise liability has been most often applied where fungible, interchangeable, or non-identifiable products are involved and where the harm suffered by an individual plaintiff cannot be traced to any specific or identifiable producer or manufacturer of a product. For example, a plaintiff had smoked cigarettes for over forty years and during that time may have smoked over forty different brands! 
Enterprise liability may be applied where (1) the injury-causing product was manufactured by one of a small number of defendants in an industry; (2) the defendants had joint knowledge of the risks inherent in the product and possessed a joint capacity to reduce those risks; and (3) each of them failed to take steps to reduce the risk but, rather, delegated this responsibility to a trade association or to a third party.

The imposition of enterprise liability runs contrary to a core element of the common law. Under the common law, an essential element of a cause of action in tort is that there must be some reasonable connection between the act or omission of a defendant and the injury suffered by a plaintiff (e.g., Klein, 2008). This is referred to as the causation requirement. As a result, a majority of courts which have considered DES claims have held that a cause of action does not exist unless the plaintiff can identify with specificity the manufacturer of the drug which allegedly caused injury. In another context, for example, in Cummins v. Firestone Tire \& Rubber Co. (1985), the plaintiff was not able to identify the particular manufacturer of tire and rim assembly that caused him injury. As a result, the Cummins court decided that the plaintiff could not maintain a negligence action against one of several such manufacturers.

The concept of enterprise liability was articulated in Hall v. E.I. DuPont De Nemours Co. (1972). In Hall, the plaintiffs were thirteen children who had sustained injuries in separate incidents as a result of exploding blasting caps. Although the plaintiffs were unable to identify the particular manufacturers responsible for their individual injuries, the plaintiffs brought an action against six blasting cap producers which comprised virtually the entire blasting cap industry in the United States. There was evidence that these defendants had adhered to an industrywide standard regarding safety features of blasting caps, and that they had delegated the responsibility for investigating safer product designs to their trade association. The court in Hall concluded that the plaintiffs had sufficiently stated a cause of action. The defendants' joint knowledge of the risks inherent in their product and a shared capacity to reduce those risks imposed upon them a duty to act, for the failure of which they could be held liable. However, the court issued a caution: "[w]hat would be fair and feasible with regard to an industry of five or ten producers might be manifestly unreasonable if applied to a decentralized industry composed of thousands of small producers" (p. 378). This comment would prove crucial in future cases.

These same conditions were underscored by a New York court in Hymowitz v. Eli Lilly \& Co. (1989), where the court noted that liability in part "rests on the notion that where there is a small number of possible wrongdoers, all of whom breached a duty to the plaintiff, the likelihood that any one of them injured the plaintiff is relatively high, so that forcing them to exonerate themselves, or be held liable, is not unfair." (p. 1074; see also Rheingold, 1989; McGuire, 1991) — although Wilson (2012) and others have strongly argued against the imposition of liability in this case. Would the same result obtain in Burnside v. Abbott Laboratories?

\subsection{Case Study: Burnside v. Abbott Laboratories (1985)}

Five women brought separate tort claims against various pharmaceutical companies who had allegedly negligently manufactured DES. Four of the women alleged that the drug had been ingested by their mothers only one of the plaintiffs claimed that she had ingested the drug herself. Based on undisputed affidavits, together with other discovery documents, the trial court (the Court of Common Pleas in Pennsylvania) granted complete or partial summary judgments in favor of twenty-six named defendants whose products could not have caused the injuries sustained by the plaintiffs. In an appeal taken from the grant of these summary judgments by the trial court, the plaintiff-appellants did not dispute that the defendant-appellees' products could not have been ingested by them or their mothers. Rather, they contended that the court should nonetheless impose industry-wide liability for injuries caused by the ingestion of DES on the theory that the defendant pharmaceutical companies should be found jointly and/or severally liable [See Appendix II] because, at the time of ingesting the drug, DES was being marketed in its generic form by defendant manufacturers.

On appeal, the Pennsylvania Supreme Court voiced initial skepticism that the application of enterprise liability was appropriate in these cases. The court noted that the plaintiffs may have suggested possible alternative theories "in an effort to circumvent the need to identify the manufacturer responsible for causing injury" (Sheiner, 1981, pp. 670-672). However, despite this skepticism, the court agreed to determine whether the appellants had alleged facts sufficient to support the enterprise liability theory which they had advanced.

In its decision, the Pennsylvania Supreme Court found that the defendants were not engaged in the "manufacture, promotion, or marketing" of DES, thus not falling within the plaintiffs' description of the "industry." 
In reaching this decision, the court noted that there were significant differences between the facts established in $\mathrm{Hall}$ and the facts established in DES cases, concluding that those differences supported the rejection of enterprise liability in DES cases. The court noted that here were only six blasting cap manufacturers in Hall; whereas, the total number of DES manufacturers was over two hundred. In addition, the court found that the complaints did not suggest that the pharmaceutical defendants possessed a joint capacity for reducing the risks inherent in DES.

The plaintiffs also did not allege that the defendant drug companies had avoided their responsibility to reduce the dangers of DES by contemporaneously delegating this burden to an industry trade association. Finally, the plaintiffs did not allege or show that the forty drug companies named as defendants constituted substantially the entire industry which had produced DES as a preventative for miscarriages in the 1950s. Burnside became the prevailing rule in determining liability under the enterprise theory.

\section{Another Theory of Recovery Surfaces: Market Share Liability}

Interestingly, after the trial court in Burnside had entered the summary judgment decrees from which the appeals were taken, but before the decision of the Pennsylvania Supreme Court had been entered, the Supreme Court of Washington had articulated a theory of recovery in DES cases in Martin v. Abbott Laboratories (1984), which the Washington Supreme Court termed market share liability. While the theory was not "new" in a technical sense (see, e.g., Meagher, 1981; Fischer, 1981), it certainly would receive increased scrutiny and evaluation in Martin and in other attempts to surmount the strict and sometimes insurmountable causation requirement in tort litigation (Gifford \& Pasicolan, 2006).

Plaintiff Rita Rene Martin was born on October 4, 1962. Her mother, Shirley Martin, obtained a prescription for and ingested DES from May 1962 until the date Rita Martin was born. On January 4, 1980, Rita was diagnosed with cell adenocarcinoma of the vagina. On February 21, 1980, as a result of the cancer, Rita underwent a radical hysterectomy, pelvic node dissection, and partial vaginectomy.

The Martin court noted that "like many other women who have pursued judicial remedies for injuries they allege were caused by DES, Shirley Martin cannot remember which drug company manufactured the DES she ingested." In addition, because of the passage of time and because DES was marketed generically, neither the plaintiff's physician nor her pharmacists were able to state with certainty which company manufactured or marketed the drug that the plaintiff had ingested. The only thing that the plaintiff could prove was that she had taken DES as prescribed in $100 \mathrm{mg}$. doses.

The Martin Court explained the plaintiff's burden of proof as follows:

"The plaintiff need not prove that a defendant produced or marketed the precise DES taken by the plaintiff's mother. Rather, the plaintiff need only establish by a preponderance of the evidence that a defendant produced or marketed the type (e.g., dosage, color, shape, markings, size or other identifiable characteristics) of DES taken by the plaintiff's mother; the plaintiff need not allege or prove any facts related to the time or geographic distribution of the subject DES. After the plaintiff has made out a prima facie case, the burden will then shift to the defendants to establish their freedom from liability. Individual defendants are entitled to exculpate themselves from liability by establishing, by a preponderance of the evidence, that they did not produce or market the particular type [of] DES taken by the plaintiff's mother; that they did not market the DES in the geographic area of the plaintiff mother's obtaining the drug; or that it did not distribute DES in the time period of plaintiff mother's ingestion of the drug" (Burnside, citing Martin, p. 288) (emphasis added).

Would the decision thread in Martin rendered alter the trial court in Burnside had entered its summary judgment decrees influence the decision of the Pennsylvania Supreme Court? In taking notice of the principles enunciated in Martin, the Pennsylvania Supreme Court nonetheless concluded that the defendants, in whose favor summary judgments had been entered at trial, could not be held liable on the basis of the theory of market share liability. The defendants had exculpated themselves by facts which plaintiff-appellants had accepted without dispute. "Several defendants showed that they had never manufactured or marketed DES as a miscarriage preventative. Others demonstrated that they had not manufactured DES during the period in which plaintiffs' mothers used the drug. Still others showed that they had never marketed DES in Pennsylvania" (pp. 288-289). In fact, the evidence showed that none of the appellee-defendants had marketed DES in Pennsylvania at or about the time of alleged ingestion as a miscarriage preventative in the dosage, color, shape, size or markings used by the plaintiffs or their mothers. On this basis, the Pennsylvania Supreme Court affirmed the decision of the trial court dismissing the plaintiff's cause of action. It had essentially rejected a market share theory. 


\section{Sindell v. Abbott Laborites (1980): Can It Be Distinguished?}

A second case, decided by the California Supreme Court, merits attention and review (Taylor, 1981). Wells (1981) described Sindell as opening a "new avenue" in DES litigation and marked a significant departure from previous case precedents.

The court in Sindell framed the issue as follows: may a plaintiff, injured as the result of a drug administered to her mother during pregnancy, who knows the type of drug involved, but cannot identify with specificity the manufacturer of the drug which caused the injury, hold a maker or makers of one or more of a group of drug produced from an identical formula liable for her injury?

Plaintiff Judith Sindell brought an action against eleven drug companies on behalf of herself and other women similarly situated. The complaint alleged as follows:

- Between 1941 and 1971, defendants were engaged in the business of "manufacturing, promoting, and marketing" DES. In 1947, the Food and Drug Administration authorized the marketing of DES as a miscarriage preventative, but only on an experimental basis, with a requirement that the drug contain a warning label to that effect.

- Thirty years later, in 1971, the Food and Drug Administration ordered defendants to cease marketing and promoting DES for the purpose of preventing miscarriages, and to warn physicians and the public that the drug should not be used by pregnant women because of the danger to their unborn children.

The lawsuit filed by the plaintiff alleged as follows:

"... that during the period defendants marketed DES, they knew or should have known that DES was a carcinogenic substance, that there was a grave danger after varying periods of latency it would cause cancerous and precancerous growths in the daughters of the mothers who took it, and that it was ineffective to prevent miscarriage. Nevertheless, defendants continued to advertise and market the drug as a miscarriage preventative. They failed to test DES for efficacy and safety; the tests performed by others, upon which they relied, indicated that it was not safe or effective. In violation of the authorization of the Food and Drug Administration, defendants marketed DES on an unlimited basis rather than as an experimental drug, and they failed to warn of its potential danger" (p. 920).

At the core of the complaint, the plaintiff claimed that the defendants had acted in a grossly negligent manner in its "manufacturing process, design, and marking activities." Because the defendants had repeatedly made assurances that DES was safe and effective to prevent miscarriage, the plaintiff was exposed to the drug prior to her birth while in her mother's womb. As a result of the DES that had been ingested by her mother, Sindell developed a malignant bladder tumor which required removal by surgery. Sindell averred that she suffered from adenosis and required constant monitoring by biopsy or colposcopy (a procedure that permits a doctor to take a close look at the cervix) to insure that she would have an early warning of any further malignancy.

The complaint filed by Sindell alleged that the defendants were jointly and individually grossly negligent (Phillips, Terry, Vandall, and Werthheimer, 2002, p. 700), because they had "manufactured, marketed, and promoted" DES as a safe and efficacious drug to prevent miscarriage, without adequate testing or warning, and without monitoring or reporting its effects. The plaintiffs (sometimes known as "DES Daughters") further alleged that defendants were jointly liable regardless of which particular brand of DES was ingested by plaintiff's mother because defendants had "collaborated in marketing, promoting and testing the drug, relied upon each other's tests, and adhered to an industry-wide safety standard." In fact, plaintiff's evidence showed that DES was produced from a common and mutually agreed upon formula and was essentially as a fungible drug, interchangeable with other brands of the same product. Sindell claimed that defendants knew or should have known that it was customary for doctors to prescribe the drug by its generic rather than its brand name; and that pharmacists filled prescriptions from whatever brand of the drug happened to be in stock at that time in the pharmacy.

Other causes of action brought by Sindell were based upon more traditional theories (Hunter, Shannon, and Amoroso, 2012, Chapter 1, pp. 1-4) such as strict liability in tort, violation of express and implied warranties, false and fraudulent representations, misbranding of drugs in violation of federal law, conspiracy and "lack of consent".

Each cause of action alleged that defendants were jointly liable because they had acted in concert, on the basis of express and implied agreements, and in reliance upon and "ratification and exploitation of each other's testing and marketing methods." 
The plaintiff sought compensatory damages of $\$ 1$ million and punitive damages of $\$ 10$ million for herself (see generally Hunter, Shannon, Amoroso, and Lozada, 2017). For the members of her class, the plaintiff sought equitable relief in the form of a court order that would require defendants to warn physicians and others of the danger of DES and the necessity of performing certain tests to determine the presence of disease caused by the drug, and that the defendants should be required to establish free clinics in California to perform such tests.

(The plaintiff class consisted of "girls and women who are residents of California and who have been exposed to DES before birth and who may or may not know that fact or the dangers" to which they were exposed.) Defendants demurred to the complaint. (A demurrer is an assertion by the defendant that although the facts alleged by the plaintiff in the complaint may be true, they do not entitle the plaintiff to prevail in the lawsuits a matter of law.) While the complaint did not expressly state that Sindell could not identify the manufacturer of the precise drug ingested by her mother, Sindell stated that she was unable to make the identification. As a result, applying the traditional common law rule relating to causation which required a plaintiff to identify the specific manufacturer that produced the defective drug which caused the plaintiff's injury, the trial court sustained the demurrers raised by the defendants without leave to amend (effectively ending the plaintiffs' quest for compensation - and some would say justice) on the ground that plaintiff had not, and stated she could not, identify which defendant had manufactured the drug responsible for her injuries. Taking note of Summers v. Tice (1949), the circumstances of the plaintiff's injury appeared to render identification of the manufacturer of the drug ingested by plaintiff's mother impossible by either plaintiff or defendants. Under these circumstances, the Sindell court noted that "it cannot reasonably be said that one is in a better position than the other to make the identification. Because many years elapsed between the time the drug was taken and the manifestation of plaintiff's injuries she, and many other daughters of mothers who took DES, are unable to make such identification" (p. 930).

As a matter of fact, a drug manufacturer ordinarily will have no direct contact with the patients who take a drug prescribed by their own physicians. In deconstructing the typical vertical marketing chain, the manufacturer will normally sell to or deal with wholesalers, who then in turn supply the product to physicians and pharmacies. Under these circumstances, "manufacturers do not maintain records of the persons who take the drugs they produce, and the selection of the medication is made by the physician rather than the manufacturer." While the plaintiff had alleged that the defendant manufacturer had produced a defective product with delayed effects and without providing adequate warnings, "the difficulty or impossibility of identification results primarily from the passage of time rather than from their allegedly negligent acts of failing to provide adequate warnings" (p. 930).

\subsection{The Court's Decision}

The court ruled that while it is certainly true that defendant drug manufacturers do not have a means superior to plaintiff to identify the maker of the precise drug taken by her mother, defendants may in some instances be able to prove that they did not manufacture the injury-causing substance - in essence, shifting the burden of proof to the defendant - at least as to this issue (see Henderson, Pearson, Kysar, and Siciliano, 2007, p. 126)..

Interestingly, the Sindell court referenced "enterprise liability" in its decision. In her complaint, Sindell had stated a cause of action under the rationale of Hall v. E.I. DuPont De Nemours Co., alleging a joint enterprise and collaboration among defendants in the "production, marketing, promotion and testing of DES," and "concerted promulgation and adherence to industry-wide testing, safety, warning and efficacy standards" for the drug. The court concluded that allegations that defendants had relied upon one another's testing and promotion methods did not state a cause of action for concerted conduct under the theory of industry-wide or enterprise liability; however, each manufacturer could be held liable for all injuries caused by DES by virtue of adherence to an industry-wide standard of safety to which tit had adhered.

In the end, the Sindell court accepted in general terms a market share analysis, but declined to apply the enterprise theory. The facts established in Sindell may have determined the outcome as to its finding regarding enterprise liability. While at least 200 manufacturers produced DES, Hall had involved 6 manufacturers which represented the entire blasting cap industry in the United States. It is well to remember that the Hall court had cautioned against application of the enterprise liability doctrine in case which involved a large number of producers (Hall, $\mathrm{p}$. 378). As the court in Sindell noted, "there is no rational basis upon which to infer that any defendant in this action caused plaintiff's injuries, nor even a reasonable possibility that they were responsible." As a result, the court determined that "defendants appear to be correct that the rule, as previously applied, cannot relieve plaintiff of the burden of proving the identity of the manufacturer which made the drug causing her injuries" (Sindell, p. 931). 
[By referencing the Restatement of Torts $2 d$, Section 876 , comment $\mathrm{b}$, the court determined that the allegations regarding "concerted action" were insufficient because the plaintiffs were unable to prove that there was either a tacit understanding or a common plan among defendants to fail to conduct adequate tests or provide sufficient warnings, or that the defendants had substantially aided and encouraged one another in these omissions (Sindell, p. 932).]

The court was not "unmindful" of several inherent difficulties in its ruling that applied market share liability as to the damages that a defendant might be required to pay, noting that "The presence in the action of a substantial share of the appropriate market also provides a ready means to apportion damages among the defendants. Each defendant will be held liable for the proportion of the judgment represented by its share of that market unless it demonstrates that it could not have made the product which caused plaintiff's injuries" (Sindell, p. 937). In fact, one DES manufacturer was dismissed from the action upon demonstrating that that it had not manufactured DES until after plaintiff was born.

Under the market share approach, the liability of each DES manufacturer would approximate its responsibility for the injuries caused by its own products and not on the basis of a more encompassing joint and several liability. The Sindell court recognized that there might be "some minor discrepancy in the correlation between market share and liability." However, "the difficulty of apportioning damages among the defendant producers in exact relation to their market share does not seriously militate against the rule we adopt" (p. 938).

\section{Conclusions and Commentary}

Market share liability, alternative liability, and enterprise liability approaches have been subject to severe criticism as "social engineering, more appropriate for the legislature" and not for courts. Indeed, the court in Sindell may have underscored the inherent difficulty of applying an imprecise doctrine relating to causation and the formula designed to assess damages when it noted: "As we said in Summers with regard to the liability of independent tortfeasors, where a correct division of liability cannot be made 'the trier of fact may make it the best it can"" (Summers v. Tice, 1948, p. 88). Some may feel uncomfortable with such a formulation and, a result, the vast majority of courts which have considered the issue have adhered to the traditional rule of causation. As Wajert (2013) stated, "Flawed and unfair, the concept did not gain wide acceptance."

There is, in addition, a practical consideration. The court in Sindell noted that it is important to recognize that the drug industry in the United States is closely regulated by the Food and Drug Administration, an agency which actively controls and monitors the testing and manufacture of drugs and the method by which drugs are marketed, including the contents of warning labels. "To a considerable degree, therefore, the standards followed by drug manufacturers are suggested or compelled by the government" through a process known as preemption (see Cipollone v Liggett Group, Inc., 1986). Failure to follow prescribed standards might result in the imposition of a finding of negligence per se (contra, Blomquist, 2009); however, it is equally true that adherence to those standards may not protect a manufacturer from the imposition of liability if a court (or jury) determines that in retrospect, the manufacturer who was apprised of additional facts or who came upon "new knowledge risk" should have "done more" (Stevens v. Parke, Davis \& Co., 1973). As the court opined in Sindell, "since the government plays such a pervasive role in formulating the criteria for the testing and marketing of drugs, it would be unfair to impose upon a manufacturer liability for injuries resulting from the use of a drug which it did not supply simply because it followed the standards of the industry" (p. 935).

While the theories of enterprise liability and alternative liability have not met with widespread acceptance in the courts, plaintiffs have "attempted to assert market share theory in a variety of contexts" (Bonanno, 1991). The results have been mostly negative in a variety of cases. For example:

- Asbestos: In Leng v. Celotex (1990), where the court failed to apply market share liability on the ground that asbestos is not fungible (see also In re Fibreboard Corp., 1990; Becker v. Baron Bros., 1994; Cimino v. Raymark Industries, Inc., 1998; Greene, 2008);

- Automobile parts: In York v. Lunkes (1989), where the court failed to apply market share liability since "car batteries are "readily distinguishable from one another" and not all batteries are defective;

- Cosmetic Breast Implants: In Lee v. Baxter Healthcare Corp. (1990), noting that Maryland did not recognize market share liability; 
- Tobacco: In Phillips v. R.J. Reynolds Industries (1988), a Tennessee appellate court ruled that the plaintiff's market share products liability action against a cigarette manufacturer was preempted by the Federal Cigarette Labeling and Advertising Act (1969);

- Vaccines: In Poole v. Alpha Therapeutic Corp. (1988), an Illinois court refused to impose market share liability. Similarly, in Shackil v. Lederle Laboratories (1989), a New Jersey court rejected the market share theory because the imposition of the theory would inevitably reduce the availability and development of drugs and vaccines. [However, it should be noted that in one case, Ray v. Cutter Laboratories (1991), a Florida court imposed liability against manufacturers of blood plasma containing the AIDS virus-but perhaps on public policy grounds.]

- Lead paint litigation (see Santiago v. Sherwin Williams Co., 1993; Lepage, 1995; Gifford, 2006).

- Handguns: Hamilton v. Beretta Corp., 2001).

\subsection{Are There Policy Arguments for the Expansion of Liability?}

Despite the general rejection of the enterprise liability theory, at the same time, there are also strong policy grounds for at least considering moving beyond the traditional formulation of liability and causation principles at least in DES litigation - and perhaps in other areas where defective products have resulted in injury to otherwise innocent or unsuspecting plaintiffs who rely on the drug manufacturer for their health and safety.

Some of these considerations raised as to DES, but which may be more universally applied, include:

- The most persuasive reason for finding that the plaintiff has stated a cause of action is that the negligent defendants should bear the cost of the injury.

- The plaintiff is not "at fault" in failing to provide evidence of causation against a particular defendant.

- The conduct of a manufacturer in marketing a drug, the "effects of which are delayed for many years," played a significant role in creating the unavailability of proof.

- Defendants are in a better position to bear the cost of injury resulting from the manufacture of a defective product.

- When pharmaceuticals are involved, the consumer is virtually helpless to protect himself from serious injuries.

- It is reasonable to hold any of the defendants who supplied the product liable for the percentage of DES which they sold.

- The burden of proof is then shifted to the individual defendants to prove that it did not produce the drug that caused the injury. And,

- Each defendant who has been unable to exculpate itself from liability will be held liable for its percentage of market share.

\subsection{Balancing the Rights and Responsibilities of the Parties}

In balancing these considerations, several policy questions will continue to be raised which will require further discussion and refinement both among the public and within the legal community:

- Is it fundamentally fair (Schoen, Hogan, and Falchek, 2000) to transfer liability to an entire industry through the imposition of enterprise liability irrespective of an individual manufacturer's connection with a particular injury?

- Is the theory of enterprise liability simply a reaffirmation of strict liability in tort (e.g., Keating, 2001)?

- Should liability be based on "the traditional rule in the United States [that] has been that tortfeasors whose acts concur to injure the plaintiff are 'jointly and severally liable' for the plaintiff's injuries" (Phillips, Terry, Vandall, and Werthheimer, 2002, p. 700)?

- Who will pay for the increased possibility of liability (Priest, 2010)? The corporation? Its shareholders or the public through increased "passed-on" costs?

- Who is in a better position to absorb the costs of the defective drug? The manufacturer or the injured party?

- Are punitive damages appropriate under the theory of market share liability (Nick, 2008)?

- Is market share liability appropriate for nonfungible products (Rostron, 2004) or for generic drugs (Friedman, 2017)?

- In considering the application of these alternate theories, once the burden of proof is shifted to a particular defendant, what amount (quantum) of proof will be required for the defendant to exculpate it from liability? 
- In establishing market share liability, how do we ascertain the extent of damages that can be apportioned against an individual manufacturer in terms of the "relevant market"? At what point in time? At the time of manufacturing the product or at the time of the filing of a lawsuit?

One thing is certain. There is still no general consensus regarding the issues that have been raised. The debate will no doubt continue whether pharmaceutical manufacturers should be able to hide behind the traditional requirements of causation relating to identifying the precise cause of injury or the identity of a party that caused the injury to a plaintiff with impunity. Whether, and under what circumstances, courts will adopt alternative liability, enterprise liability, or more likely market share liability will continue to be worked out in the future.

It does appear, however, that market share liability provides a middle ground in the debate and one that can be managed by the pharmaceutical industry. Thus, the adoption of market share liability has the best chance of developing as a basis of finding causation in products liability suits and thus as a source of compensation for injured plaintiffs.

It does appear that the adoption of enterprise or industry-wide liability may have been a "bridge too far" for courts to cross who have been guided by traditional rules relating to causation. A single manufacturer could have been forced to page huge damage awards on the basis of the application of joint and several liability. However, the market share theory, accompanied by appropriate procedural safeguards, may be the appropriate vehicle to bridge that gap. At least three states - California, New York, and Florida-have recognized its validity under a limited range of cases. Of course, on the other side of the equation is perhaps the larger question: is the limitation of liability under market share liability fair to a plaintiff who has suffered injury through no fault of their own?

\section{References}

Blomquist, R.F. 2009. The trouble with negligence per se. South Carolina Law Review, 61: 221-286.

Boeschen, C. 2018. "Failure to warn" in a defective product case. Available: http://www.allaw.com/articles/nolo/personal-injury/failure-to-warn-defective-product-case.html.

Bonanno, S. 1991. Presumed innocent: Illinois' rejection of market share liability in Smith v. Eli Lilly \& Company is cause in fact to celebrate. John Marshall Law Review, 24: 869-890.

Federal Cigarette Labeling and Advertising Act. 1965. 79 Stat. 282.

Fischer, D.A. 1981. Products Liability: an analysis of market share liability. Vanderbilt Law Review, 34: 16231662.

Friedman, E \& Wickelgren, A.L. 2017. Who (If anyone) should be liable for injuries from generic drugs? Journal of Law, Economics, and Organization, 33(3): 541-577.

Geistfeld, M.A. 2006a. Principles of products liability. New York: Foundation Press.

Geistfeld, M.A. 2006b. The doctrinal utility of alternative liability and market-share liability. University of Pennsylvania Law Review, 155(2): 447-501.

Gifford, D.G. \& Pasicolan, P. 2008. Market share liability beyond DES cases: the solution to the causation dilemma in lead paint litigation? South Carolina Law Review, 58: 115-159. Available: http://digitalcommons.law.umaryland.edu/fac_pubs.

Greene, C.T. 2008. Determining liability in asbestos cases: the battle to assign liability decades after exposure. American Journal of Trial Advocacy, 31: 571-600.

Henderson, J.A., Pearson, R.., Kysar, D.A, \& Siciliano, J.A. 2007. The torts process ( $7^{\text {th }}$ ed.). New York: Aspen Publishers.

Hunter, R.J. \& D. Jason. 2014. Products liability in the pharmaceutical industry. International Journal of Advances in Social Sciences and Humanities, 2(7): 12-20.

Hunter, R.J, Jr., Shannon, J.H. \& Amoroso, H.J. 2012. Products liability: a managerial approach. North Charleston, S.C.: Create Space.

Hunter, R., Jr., Shannon, J.H., Amoroso, H.J., \& Lozada, H.R. 2017. A reprise of compensatory and general damages in products liability cases. International Journal of Business Management and Commerce, 2(1): 24-37.

Keating, G.C. 2001. The theory of enterprise liability and common law strict liability. Vanderbilt Law Review, 54(3): 1285-1335.

Klein, A.R. 2008. Causation and uncertainty: making connections in a time of change. Jurimetrics, 49(1): 5-50.

Klemme, H. 1976. The enterprise liability theory of torts. University of Colorado Law Review, 47: 153-232. 
Larson, A. 2018. Negligence and tort law. Available: https://www.expertlaw.com/library/personal_injury/negligence.html.

LawyersandSettlements.com. 2018. DES lawsuits. Available: https://www.lawyersandsettlements.com/lawsuit/diethylstilbestrol.html.

Legal Information Institute, 2018. Joint and several liability. Available: https://www.law.cornell.edu/wex/joint_and_several_liability.

Lepage, K.R. 1995. Lead-based paint litigation and the problem of causation: toward a unified theory of market share liability. Boston College Law Review, 37: 155-182.

McGuire, C.J. 1991. Market-share liability after Hymowitz and Conley. University of Michigan Journal of Law Reform, 24: 759-783.

Meagher, P.A. 1981. Market share liability: a new method of recovery for D.E.S. litigants. Catholic University Law Review, 30: 551-582.

Nick, A.B. 2008. Market share liability \& punitive damages: the case for evolution in tort law. Columbia Journal of Law and Social Problems, 42(2): 225-260.

Pham, D. 2014. Ethical, legal, and regulatory issues regarding the study and use of medications in pregnant women. Journal of Commercial Biotechnology, 20(3). Available: DOI:10.5912/jcb665

Phillips, J.J., Terry, N.P., Vandall, F.J., \& Werthheimer, E. 2002. Products liability: cases, materials, problems. Newark, N.J.: Lexis-Nexis.

Priest, G.L. 2010. Market share liability in personal injury and public nuisance litigation: an economic analysis. Supreme Court Economic Review, 18(1): 109-133.

Restatement 2d Torts. 1977/1979.

Rheingold, P.D. 1989. The Hymowitz decision: practical aspects of New York DES litigation. Brooklyn Law Review, 55: 883-897.

Rostron, A. 2004. Beyond market share liability: a theory of proportional share liability for non fungible products. UCLA Law Review, 52(1): 151-215.

Sheiner, N. 1978. DES and a proposed theory of enterprise liability. Fordham Law Review, 46(5): 963-1007.

Schoen, E.J., Hogan, M.M, \& Falchek, J.S. 2000. An examination of the legal and ethical public policy consideration underlying DES market share liability. Journal of Business Ethics, 24(2): 141-163.

Taylor, N.D. 1981. California expands tort liability under the novel market share theory: Sindell v. Abbott Laboratories, Pepperdine Law Review, 8(4): 1010-1043. Available: https://digitalcommons.pepperdine.edu/plr/vol8/iss4/4.

Twerski, A \& Henderson, J.A., Jr. 2009. Manufacturer's liability for defective product designs: the triumph of risk utility. Brooklyn Law Review, 74(3): 1061-1108. Available: Cornell Law Faculty Publications, Paper 794. Available: http://scholarship.law.cornell.edu/facpub/794.

Wajert, S. 2013. DES plaintiff's reach for market share liability rejected again. Available: http://www.masstortdefense.com/2013/01/articles/des-plaintiffs-reach-for-market-share-liability-rejectedagain/.

Wells, M.H. 1981. Sindell v. Abbott Laboratories: a new avenue for DES litigation. Golden Gate University Law Review, 11(3): 917-943.

Wilson, W.D. 2012. Market share liability: did New York go too far?: Hymowitz v. Eli Lilly \& Co. St. John's Law Review, 64(2): 363-377.

\section{CASES}

Becker v. Baron Bros. 1994. 649 A.2d 613 (New Jersey Supreme Court).

Bezuidenhout v. Abbott Laboratories. 2013. 918 F. Supp.2d 144 (United States District Court, Eastern District of New York).

Burnside v. Abbott Laboratories. 1985. 351 Pa. Superior Ct. 264 (Pennsylvania Supreme Court).

Cimino v. Raymark Industries, Inc. 1998. 151 F.3d 297 (United States Court of Appeals, Fifth Circuit).

Cipollone v. Liggett Group, Inc. 1992. 505 U.S. 504 (United States Supreme Court).

Cummins v. Firestone Tire \& Rubber Co. 1985. 344 Pa. Super. 9, 495 A.2d 963 (Pennsylvania Superior Court).

Escola v. Coca-Cola Bottling Co. of Fresno. 1944. 150 P.2d 436 (California Supreme Court).

Hall v. E.I. DuPont De Nemours Co. 1972. 345 F. Supp. 353 (United States District Court, Eastern District of New York). 
Hamilton v. Beretta Corp. 2001. 727 N.Y.S. 2d (New York Court of Appeals).

Hymowitz v. Eli Lilly \& Co. 1989. 539 N.E.2d 1069 (New York Court of Appeals).

In re Fibreboard Corp. 1990. 893 F.2d 706 (United States Court of Appeals, Fifth Circuit).

Lee v. Baxter Healthcare Corp. 1989. 721 F. Supp. 89 (United States District Court, Maryland).

Leng v. Celotex. 1990. 554 N.E.2d 465 (Illinois Court of Appeals).

Martin v. Abbott Laboratories. 1984. 689 P.2d 581 (Washington Supreme Court).

Phillips v. R.J. Reynolds Industries. 1988. 769 S.W.2d 488 (Tennessee Court of Appeals, Eastern Section).

Poole v. Alpha Therapeutic Corp. 1988. 696 F. Supp. 351 (United States District Court, Northern District of Illinois).

Ray v. Alad Corp. 1977. 19 Cal. 3d 22, 136 Cal. Rptr. 574 (California Supreme Court).

Ray v. Cutter Laboratories. 1991. 754 F. Supp. 193 (United States District Court, Middle District of Florida).

Santiago v. Sherwin Williams Co. 1993. 3 F.3d 546 (United States Court of Appeals, First Circuit).

Shackil v. Lederle Laboratories. 1989. 116 N. 155 (New Jersey Supreme Court).

Shunk v. Bosworth. 1964. 334 F.2d 309. (United States Court of Appeals, Sixth Circuit).

Sindell v. Abbott Laboratories. 1980. 607 P.2d 924 (California Supreme Court).

Spruill v. Boyle-Midway Corporation. 1962. 308 F.2d 79 (United States Court of Appeals, Fourth Circuit).

Stevens v. Parke, Davis \& Co. 1973. 507 P.2d 653 (California Supreme Court).

Summers v. Tice. 1948. 33 Cal. 2d 80 (California Court of Appeals).

Wetzel v. Eaton Corporation. 1973. 62 F.R.D. 22 (Minnesota District Court).

Ybarra v. Spangard. 1944. 25 Cal. 2d 486, 154 P.2d 687 (California Supreme Court).

York v. Lunkes. 1989. 545 N.E.2d 478 (Illinois Appellate).

\section{Appendix I: Corporate Defendants In Des Cases}

\section{Burnside V. Abbott Laboritories:}

Abbott Laboratories

Adria Laboratories, Inc., a subsidiary of Hercules, Inc.

Alcon Laboratories, Inc.

Amfre-Grant, Inc., a subsidiary of Ormont Drug and Chemical

Armour Pharmaceutical Co., a subsidiary of Revlon, Inc.

Breon Laboratories, Inc., a subsidiary of Sterling Drug, Inc.

Burroughs Wellcome Company, a subsidiary of the Wellcome Foundation, Inc.

C.D. Smith Drug Company

Carnrick Laboratories, a division of G.W. Carnrick Company

Chemetron Corporation

Cole Pharmacal Company, Inc., a subsidiary of O'Neal, Jones \& Feldman, Inc.

Dorsey Laboratories, a division of Sandoz, Inc.

Drug Products Company, Inc.

E.R. Squibb \& Sons, Inc., a subsidiary of Squibb Corporation

Eli Lilly \& Co.

Kramers-Urban Company

Merck \& Company, Inc.

Merck, Sharp \& Dohme, a division of Merck and Company

Merrell-Dow Pharmaceuticals, a division of Richardson-Merrell

Miller Pharmacy Group

National Drug Company, a division of Richardson-Merrell, Inc.

Physicians Drug \& Supply Company

Physicians \& Hospitals Supply Company

Premo Pharmaceutical Laboratories, Inc.

Revlon, Inc.

Rexall Drug Company

Richardson-Merrell, Inc.

Rowell Laboratories, Inc.

Sandoz, Inc.

Smith-Dorsey Sterling Drug Company, Inc.

Squibb Corporation

Ulmer Pharmacal Company, a division of Physicians \& Hospitals Supply Company 
Upjohn Company

Vale Chemical Company

Vitamins, Inc.

Wander Company

Warren-Teed Pharmaceuticals, Inc., a subsidiary of Rohm and Haas Co.

Webcon Pharmaceuticals Company, a subsidiary of Alcon Laboratories

William H. Rorer, Inc.

William S. Merrell Company, a division of Richardson-Merrell, Inc.

\section{Martin V. Abbott Laboratories:}

Abbott Laboratories

Approved Pharmaceutical Corporation

Armour Pharmaceutical Company

Ayerst Laboratories, Inc.

Breon Laboratories, Inc.

Carnrick Laboratories, Inc.

Corvid Pharmaceuticals

Eli Lilly and Company

Kirkman Laboratories, Inc.

Merck and Company, Inc.

Hill Pharmaceutical, Inc.

Penn Herb Company, Ltd.

Pharmex, Inc.

Raway Pharmaceutical Company

Rexall Drug Company

Stanley Drug Products, Inc.

Stanlabs Pharmaceutical Company

E.R. Squibb Sons, Inc.

Summers Laboratories, Inc.

The Upjohn Company

Winthrop Laboratories

Wyeth Laboratories, Inc.

[The Martins also sued pharmacist Ludwig on the theory of strict products liability for selling an unreasonably dangerous product.]

\section{Sindell V. Abbott Laboratories:}

Abbott Laboratories

Armour Pharmaceutical Co.

Ayerst Laboratories

Breon Laboratories

Eli Lilly

E.R. Squibb \& Sons.

Kirkman Laboratories

Ludwig

Merck and Co.

Raway Pharmaceutical Co.

Rexall Drug Co.

Stanlabs Pharmaceutical Co.

Upjohn Co.

Winthrop Laboratories.

Wyeth Laboratories

\section{Appendix Ii: Joint And Several Liability}

"When two or more parties are jointly and severally liable for a tortious act, each party is independently liable for the full extent of the injuries stemming from the tortious act. Thus, if a plaintiff wins a money judgment against the parties collectively, the plaintiff collect the full value of the judgment from any one of them. That party may then seek contribution the other wrong-doers. This concept of choosing the defendant(s) from whom to collect damages is called the law of indivisible injury." [Legal Information Institute, 2018] 